\title{
Evaluating Utility of C - Reactive Protein in Differentiating Bacterial from Non- Bacterial Meningitis in Tertiary Care Hospital, in Central India
}

\author{
Patel $\mathbf{N}^{1}$, Patel $\mathbf{U}^{2}$, Nagpal AC ${ }^{3}$, Jain $\mathrm{RK}^{4}$ \\ ${ }^{1}$ Dr. Narmada Prasad Patel, Assistant Professor, Department of medicine, ${ }^{2}$ Dr Umesh Patel, Both from L.N. Medical College, \\ Bhopal, India , ${ }^{3}$ Dr A C Nagpal, ${ }^{4}$ Dr R K Jain, Both from N C S B Medical College, Jabalpur, India
}

Address for correspondence: Dr Narmada Patel, Email-: narmadapatel2006@rediffmail.com

\begin{abstract}
Introduction: Prognosis of CNS infection is critically depends on rapid diagnosis and early implementation of an accurate treatment. Signs and symptoms of CNS infections remain more or less same at the time of initial presentation. Biochemical and cellular analysis of cerebrospinal fluid (CSF) remains main tool in differentiating between Pyogenic meningitis, tubercular meningitis and viral encephalitis. The results of CSF analysis are time consuming and empirical therapy has to start awaiting results of CSF analysis. The authors did a study to evaluate the efficacy of CSF- CRP in differentiating between bacterial and aseptic (viral) meningitis at bedside. Material and method: In the present study C - Reactive Protein (CRP) in Cerebrospinal fluid (CSF) were studied with latex agglutination method in 58 cases. The authors recruited patients clinically diagnosed as having acute meningitis in department of Medicine, NSCB Medical College, Jabalpur, Madhya Pradesh (India). Results: CSF-CRP was positive in 15 (83.3\%) out of 18 in Pyogenic meningitis, 5 (25\%) out of 20 in Tubercular meningitis. CSF-CRP levels in all case of Encephalitis (total of 10) and control (total of 10) were negative. Conclusion: Measurement of CSF-CRP with latex agglutination can be a good parameter in diagnosis and differentiation of C.N.S infections. Since CRP in CSF can be performed bedside, easy to process, take minimum time and most important very cheap, it can be very useful tool in early initiation of accurate treatment before detail CSF parameters are available and hence improve patient's outcome in bacterial and nonbacterial meningitis.
\end{abstract}

Key words: C Reactive protein (CRP), Cerebrospinal fluid (CSF), Meningitis.

\section{Introduction}

Rapid diagnosis in CNS infections is believed to be essential to avoid poor outcome. Signs and symptoms of CNS infections remain more or less same at the time of initial presentation. It is very difficult to differentiate between pyogenic meningitis, tubercular meningitis and viral encephalitis clinically. Biochemical and cellular analysis of Cerebrospinal fluid still remains the main tool in diagnosing and differentiation of various common infection. CSF analysis is often time consuming and the treatment has to be started empirically without awaiting for results of the same.

Manuscript received: $15^{\text {th }}$ May 2013

Reviewed: $16^{\text {th }}$ May 2013

Author Corrected; $29^{\text {th }}$ May 2013

Accepted for Publication: $30^{\text {th }}$ May 2013

International Journal of Medical Research and Review
Prognosis of CNS infection is critically depends on rapid causal diagnosis and implementation of an accurate treatment. Therefore, the initial treatment of CNS infection is still most of the time presumptive and definitive diagnosis often established when therapeutic management has already been established.

Thus, it is necessary to distinguish them from one another, remembering that management differs vastly. This become further important in Indian government hospital setting where majority of meningitis patients are getting treatment and detail CSF analysis report are often delayed and are not very reliable due to variety of practical reasons behind it.

Meningitis is an inflammation of the meninges, the layer of tissue that surrounds the brain and the spinal cord. Available online at: www.ijmrr.in 47 | P a g e 
Inflammation may be infectious or non infectious in origin. The usual cause of meningitis is an infection with a microbe, which can be bacterial, tubercular, viral, fungal or protozoal. The diffentiation between viral and bacterial meningitis is very important in treatment ${ }^{1,2}$

Treatment depends on causative agent. Meningitis can be a fatal if not diagnosed and treated promptly, and survivors can experience significant disability. Close monitoring of patients with meningitis by clinical sign, symptoms and laboratory test is important.

Several reports have shown an ability of C-reactive protein (CRP) to discriminate between patients with bacterial meningitis and patients with aseptic (viral) meningitis ${ }^{3}$. A recent meta-analysis also suggested that a negative CRP test in either cerebrospinal fluid (CSF) or serum can be used with a very high probability to rule out bacterial meningitis ${ }^{4,5,6}$.

Tillet et $\mathrm{al}^{7}$ discovered C Reactive Protein (CRP) and acute phase inflammatory responses in 1930 as a substance in the serum of patients with acute inflammation that reacted with C Polysacharide of pneumococcus. CRP is a member of class of acute phase reactant as its level rises dramatically during inflammatory process occurring in body.

Increased CRP production is an early and sensitive response to most form of microbial infection and the value of its measurement in diagnosis and management of various infective conditions has been established. Corall $(1981)^{8}$ et al first demonstrated the utility of detection of CRP in CSF to differentiate between viral and bacterial infection of CNS by using latex agglutination method and found to be $100 \%$ effective.

Collin et al (1985) ${ }^{9}$ also measured CRP in CSF both by latex agglutination and an immunoradiometric assay (IRMA) and concluded that latex agglutination although only semi quantitative is a rapid and useful method to assess CSF-Creactive protein in routine clinical practice and when positive is a strong supporting evidence for bacterial infections.

In Indian subcontinent Vaidya et al $(1987)^{2}$ had studied 150 cases by latex agglutination and suggested CRP detected by latex agglutination is a helpful screening test to differentiate bacterial and non bacterial meningitis at bed side and CRP detected patient should be considered to have bacterial meningitis until proved otherwise.
The authors did a study to evaluate the efficacy of CSF- CRP in differentiating between bacterial and aseptic (viral) meningitis at bedside.

\section{Material and Methods}

1. Study Design- It is a cross sectional study.

2. Setting \& Sampling- The authors recruited patients clinically diagnosed as having meningitis in department of Medicine, of tertiary care center in central India. Most of patients come from rural and underprivileged area that lacks proper medical facility. Study was conducted for a period of one year.

Institutional Ethics Committee approved the study. Written consent was obtained from caretaker to participate in study. Confidentiality was assured and explanation related to research were given to gain their co-operation. Selection criteria for case and control were decided.

\section{(a) Selection criteria for control}

Controls were taken from patients admitted with trivial nonneurological illnesses having no neurological sign with normal CSF examination.

\section{(b) Selection criteria for case}

Patient selected randomly admitted with history, clinical signs and CSF picture suggestive of acute meningitis. Patients with overlapping CSF picture and borderline cases were excluded from study. Patient who had received antibiotics prior to admission were also included in study.

\section{(c) Parameter assessed}

All patients were assessed for their detailed history of present illness with duration of complaints, significant past history, history of receiving drugs before admission in the hospital, history of contact with a patient of tuberculosis, any associated pyogenic infection elsewhere in body.

Detailed general examination, systemic examination of all systems with special emphasis to detailed central nervous system examination which includes state of consciousness, signs of meningeal irritation, examination of cranial nerves, examination of motor system, examination of sensory system and fundus examination. 
All the patients were assessed with CBC with ESR, X-ray chest, Monteux test, and Cerebrospinal Fluid examination to get evidence for diagnosis of meningitis.

\section{(d) Collection of Cerebrospinal Fluid:}

Taking all aseptic precautions CSF was collected drop-wise by lumber puncture. Two samples of $3 \mathrm{ml}$. each one for cellular, biochemical and direct smear examination and the other one for CRP latex agglutination lest were collected. At the same time about $2 \mathrm{cc}$. of CSF was collected directly in the culture tube for CSF culture.

The cell count protein and sugar estimation and CRP in CSF by latex agglutination method were done either immediately or within 24 hours.

A qualitative slide test utilising latex agglutination for the detection of CRP was used (as described by Corral CJ, Pepple JM et al. J. Pediatr 99,1981 )7, Ortho CRP Test (Ortho diagnostic systems, Division of Ethinor limited) was used.

\section{(e) Criteria for diagnosis:}

Diagnosis of Pyogenic meningitis was made based on history of short duration fever, headache, vomiting, convulsion, presence of some septic foci (i.e. Acute Otitis Media, Mastoditis, Boils) on general examination, Presence of signs of meningial irritation, sign of neurological deficit, sign of increased intra cranial tension etc.

with CSF routine examination showing Hazy or turbid CSF on gross appearance, Moderate to marked elevation of protein, Marked reduction or absence of glucose content of CSF, Marked elevation of cells predominantly polymorphs.

Bacteriological examination of CSF showing organism by direct smear examination or organism grown in CSF culture (not mandatory)

Diagnosis of Tubercular Meningitis was made based on History of fever, vomiting, convulsions, headache or altered sensorium of insidious onset, Social history suggestive of low socio-economic status. Past history of any immunosuppressive illness, CNS examination revealing sings of meningeal irritation signs of neurological deficit, signs of raised intracranial tension and presence of cranial nerve palsies or localized motor deficits with routine CSF examination revealing Clear fluid and formation of cob-web, Mild to moderate increase of protein contents of fluid, normal or slightly reduced sugar content, moderate elevation of cells predominantly mononuclear type of cells.

Any other findings on systemic examination supporting miliary tuberculosis, raised ESR, lymphocytosis in peripheral blood were taken as additional evidence of tubercular meningitis. History of contact with Tuberculosis was taken in all cases.

The diagnosis of encephalitis was purely clinical excluding cerebral malaria, enteric encephalopathy or metabolic cause by relevant investigations.

The clinical information supportive of encephalitis were history of moderate to high grade fever of short duration with diffuse CNS signs, Past history of any mild febrile illness suspected to be viral in origin and normal CSF examination report or borderline increase in protein contents and cell count.

\section{(f) Data Analysis}

Data management was done Visual Fox Pro 6.0 and data analysis was performed in SPSS 13.0 for window computer software.

Analysis of variance (ANOVA) was applied for comparison between the 4 study groups and main effect was observed in between the groups and within the groups. Correlation coefficient ' $r$ ' was observed to find out two continuous data set.

The number of true positives (TP), true negatives (TN), false positive (FP), and false negative (FN). Sensitivity was the calculated as $\mathrm{TP} /(\mathrm{TP}+\mathrm{FN})$, specificity as $\mathrm{TN} /(\mathrm{TN}+\mathrm{FP})$, positive predictive values ( $\mathrm{PPV}$ ) as $\mathrm{TP} /(\mathrm{TP}+\mathrm{FP})$ and negative predictive value (NPV) as $\mathrm{TN} /(\mathrm{FN}+\mathrm{T}$ 


\section{Results}

Table 01: Presenting complaints in different disease groups

\begin{tabular}{|c|c|c|c|}
\hline Complaints & Pyogenic Meningitis & Tubercular Meningitis & Viral Encephalitis \\
\hline Fever & $18(100 \%)$ & $16(80 \%)$ & $10(100 \%)$ \\
\hline Headache & $08(44.4 \%)$ & $14(70 \%)$ & $04(40 \%)$ \\
\hline Vomiting & $04(22.2 \%)$ & $04(20 \%)$ & $02(20 \%)$ \\
\hline Convulsion & 00 & $01(05 \%)$ & $04(40 \%)$ \\
\hline Altered Sensorium & $18(100 \%)$ & $15(75 \%)$ & $10(100 \%)$ \\
\hline
\end{tabular}

Fever and altered sensorium were the most common symptoms. Fever was present in $100 \%, 80 \%$ and $100 \%$ in pyogenic meningitis, tubercular meningitis and viral encephalitis respectively. Altered sensorium was present in $100 \%, 75 \%$ and $100 \%$ respectively. Headache was more marked in tubercular meningitis (70\%) and convulsions were more in viral encephalitis (40\%).

Table 02: Distribution of Positive C reactive Protein in CSF

\begin{tabular}{|l|c|c|c|c|c|}
\hline \multirow{2}{*}{ CSF-CRP } & \multicolumn{4}{|c|}{ Group } & \multirow{2}{*}{ Total } \\
\cline { 2 - 6 } & $\begin{array}{l}\text { Pyogenic } \\
\text { Meningitis }\end{array}$ & $\begin{array}{l}\text { Tubercular } \\
\text { Meningitis }\end{array}$ & $\begin{array}{c}\text { Viral } \\
\text { Encephalitis }\end{array}$ & Control \\
\hline Positive & 15 & 5 & 0 & 0 & 20 \\
& $(83.3 \%)$ & $(25.0 \%)$ & $(00.0 \%)$ & $(00.0 \%)$ & $(34.5 \%)$ \\
\hline Negative & 3 & 15 & 10 & 10 & 38 \\
& $(16.7 \%)$ & $(75.0 \%)$ & $(100.0 \%)$ & $(100.0 \%)$ & $(65.5 \%)$ \\
\hline Total & $\mathbf{1 8}$ & $\mathbf{2 0}$ & $\mathbf{1 0}$ & $\mathbf{1 0}$ & $\mathbf{5 8}$ \\
\hline
\end{tabular}

As per table 2 almost $83 \%$ patients of Pyogenic meningitis were having positive CSF CRP.

Table 03: Showing results of CRP test in Pyogenic Meningitis)

$\mathrm{Z}=3.66 \quad \mathrm{p}<0.00025$
\begin{tabular}{|c|c|c|c|}
\hline Sr No & CRP in CSF & No of cases & Percentage \\
\hline 1. & Positive & 15 & $83.3 \%$ \\
\hline 2. & Negative & 03 & $16.7 \%$ \\
\hline
\end{tabular}

CRP in CSF was positive in 15 cases of pyogenic meningitis and negative in 3 cases. It has a Sensitivity of 83.3\%, Specificity of $87.5 \%$, positive predictive value of $75 \%$ and negative predictive value of $92 \%$ in cases of Pyogenic Meningitis.

Table 04: Showing results of CRP test in Tubercular Meningitis.

\begin{tabular}{|c|c|c|c|}
\hline Sr No & CRP in CSF & No of cases & Percentage \\
\hline 1. & Positive & 5 & $25 \%$ \\
\hline 2. & Negative & 15 & $75 \%$ \\
\hline $\mathrm{Z}=2.85$ & $\mathrm{P}=0.005$ &
\end{tabular}


CRP in CSF was positive in 5 cases in tubercular meningitis group and negative in 15 cases. It has sensitivity of $25 \%$, specificity of $60.5 \%$, positive predictive value of $25 \%$ and negative predictive value of $60.5 \%$.

Table 05: Showing results of CRP test in viral encephalitis

\begin{tabular}{|c|c|c|c|}
\hline Sr No & CRP in CSF & No of cases & Percentage \\
\hline 1. & Positive & 0 & 0 \\
\hline 2. & Negative & 10 & 100 \\
\hline
\end{tabular}

CRP in CSF was negative in all cases of viral encephalitis.

Table 06: Showing results of CRP test in control group.

\begin{tabular}{|c|c|c|c|}
\hline Sr No & CRP in CSF & No of cases & Percentage \\
\hline 1. & Positive & 0 & 0 \\
\hline 2. & Negative & 10 & 100 \\
\hline
\end{tabular}

Test was negative in all control cases.

Table 07: Correlation between CSF-CRP and CSF-Protein

\begin{tabular}{|l|c|c|c|c|c|}
\hline \multirow{2}{*}{ CRP in CSF } & \multicolumn{5}{|c|}{ CSF Protein (mg \%) } \\
\cline { 2 - 6 } & $\mathbf{0 - 5 0}$ & $\mathbf{5 1 - 1 0 0}$ & $\mathbf{1 0 1 - 1 5 0}$ & $\mathbf{1 5 1 - 2 0 0}$ & $>\mathbf{2 0 0}$ \\
\hline Positive & 0 & 5 & 13 & 3 & 0 \\
\hline Negative & 9 & 17 & 1 & 3 & 1 \\
\hline Total & 9 & 22 & 13 & 3 \\
\hline $\mathrm{R}=0.551 \quad \mathrm{P}<0.002$
\end{tabular}

Table No. 07 shows that there is positive correlation between CSF Protein level and CSF-CRP positivity. CRP was positive only if CSF protein was $>50 \mathrm{mg} \%$ and maximum positivity is noted in range of $50-150 \mathrm{mg} \%$. It is statistically significant.

Table 08: Correlation between CSF CRP and CSF Cell count

\begin{tabular}{|c|c|c|c|c|c|}
\hline \multirow{2}{*}{ CRP in CSF } & \multicolumn{5}{|c|}{ Cell Count in CSF } \\
\cline { 2 - 6 } & $<\mathbf{1 0 0}$ & $\mathbf{1 0 1 - 2 0 0}$ & $\mathbf{2 0 1 - 3 0 0}$ & $\mathbf{3 0 1 - 4 0 0}$ & $>\mathbf{4 0 0}$ \\
\hline Positive & 4 & 7 & 1 & 2 & 6 \\
\hline Negative & 2 & 4 & 2 & 1 & 6 \\
\hline Total & 25 & 11 & 3 & 3 & 6 \\
\hline
\end{tabular}

$\mathrm{R}=0.301 \quad \mathrm{P}>0.05$

Table No. 08 shows that there is positive correlation in between CSF-CRP positivity and CSF Cell count, but it is not statistically significant. 
Table 09: Mean value of CBC and ESR

\begin{tabular}{|c|c|c|c|c|l|}
\hline \multirow{2}{*}{ Parameters } & \multicolumn{4}{|c|}{ Group } & \multicolumn{1}{|c|}{$\begin{array}{c}\text { ANOVA } \\
\text { Significance }\end{array}$} \\
\cline { 2 - 6 } & $\begin{array}{c}\text { Pyogenic } \\
\text { Meningitis }\end{array}$ & $\begin{array}{l}\text { Tubercular } \\
\text { Meningitis }\end{array}$ & $\begin{array}{c}\text { Viral } \\
\text { Encephalitis }\end{array}$ & Control & F=1.32 \\
\hline $\mathrm{Hb}$ & $10.4 \pm 1.6$ & $10.4 \pm 1.1$ & $9.7 \pm 1.6$ & $11.1 \pm 2.2$ & $\begin{array}{l}\mathrm{DF}-3 \\
\mathrm{P}>0.05\end{array}$ \\
\hline \multirow{2}{*}{$\mathrm{TLC}$} & $9655.6 \pm 3211.2$ & $7070 \pm 2309.7$ & $8070 \pm 2518.8$ & $5890 \pm 1755.3$ & $\begin{array}{l}\mathrm{F}=5.46 \\
\mathrm{DF}-3 \\
\mathrm{P}<0.002\end{array}$ \\
\hline $\mathrm{ESR}$ & $41.9 \pm 21.9$ & $48.7 \pm 27.2$ & $23.6 \pm 10.1$ & $17.6 \pm 6.5$ & $\begin{array}{l}\mathrm{F}=6.89 \\
\mathrm{DF}-3 \\
\mathrm{P}<0.001\end{array}$ \\
\hline
\end{tabular}

Total leukocyte count was found high in all three groups. Value was higher in pyogenic meningitis and viral encephalitis (9655 \pm 3211.2 Vs $8070 \pm 2518.8)$ than tubercular meningitis (7070 \pm 2309.7$)$. ESR value was higher in tubercular meningitis $(48.7 \pm 27.2)$ than pyogenic meningitis and viral encephalitis $(41.9 \pm 21 \& 23.6 \pm 10.1)$ respectively.

\section{Discussion}

Among the various CNS infections, pyogenic meningitis is commonest infection in infants, children and adults. In spite of glorious medical advancement and discoveries, pyogenic meningitis remains one of the most challenging emergencies of medical sciences.

Early diagnosis and treatment is essential to avoid poor outcome and long term sequelae. CNS infections are caused by variety of etiological agents and definitive treatment depends on causative agents. Symptoms and signs remain more or less same, and it is very difficult to diagnose the etiology clinically. Thus differentiation should be prompt to avoid poor outcome.

The etiological diagnosis of meningitis in developing countries remains a major problem as CSF biochemical analysis and cellular responses are time consuming and treatment has to be started empirically awaiting result of same.. This become even more difficult due to high prevalence of tubercular meningitis, as M. tuberculosis is not always easily and reliably identified in CSF by established methods.
Developing countries like India where health facilities are very much lacking diagnosis of pyogenic meningitis and starting of treatment again become challenging.

Many studied have revealed usefulness of measurement of CRP in CSF to distinguish bacterial from non-bacterial meningitis. This qualitative study was conducted to distinguish bacterial meningitis to non-bacterial meningitis at bedside. So that definitive treatment can be introduced promptly.

The reason for significantly higher value of CRP in pyogenic meningitis is that CRP production is a non specific response to tissue damage. The greater destruction of tissue caused by bacteria then by viruses might explain the higher

values. The greater CRP response may be related to extra cellular life cycle of bacteria compared with the predominantly intra cellular lifecycle of viruses.

In present study $11 \%$ case of pyogenic meningitis received antibiotic therapy prior to hospitalization thus altering CSF picture. In all these causes CRP was positive. Finding is in Available online at: $\underline{w w w . i j m r r . i n}$ 52 | P a g e 
accordance with Corall et al $(1981)^{8}$ indicating that antibiotic therapy does not alter CRP response till underlying disease activity persist. 3 cases were negative for CRP in CSF. Similar findings were reported by Barry M. Gray ${ }^{10} \&$ explanation that can be offered is that CRP response varies enormously and CRP level may less to be detected by qualitative method.

Out of 20 cases of tubercular meningitis, CRP was detected in 5 cases only $(25 \%)$. This is in accordance with the fact that CSF CRP is reflection of serum CRP. Similar finding was reported by debeers(1984) ${ }^{11}$ that higher value of serum CRP in tubercular meningitis but not as high as in pyogenic meningitis. The explanation which can be offered is probably since CRP is acute phase reactant so it was only positive in acute or early stages of TBM in present study.
The encephalitis group comprised of 10 cases. No viral studies could be performed. The diagnosis in each was arrived at on clinical grounds after exclusion of other similar condition by relevant investigations. CRP was not detectable in all patients. It was negative in all control cases. Possible explanation is that probably CRP is not present in CSF normally.

\section{Predictive value of CSF CRP}

A number of studies strongly suggested that either serum and/or CSF measurement of CRP could be reliable to discriminate between bacterial and nonbacterial CNS infection by routine clinical application. In our study results are summarize in Table

Thus it can be inferred that if the test is positive then viral encephalitis can be safely ruled out and maximum prediction of pyogenic meningitis (75\%) can be made. If the test is negative than maximum prediction $(73.7 \%)$ of viral encephalitis can be made. However the possibility of tubercular and pyogenic meningitis cannot be ruled out by negative test. A negative test is more suggestive for diagnosis of tubercular meningitis. Thus considerable overlapping exist between pyogenic and tubercular meningitis. This has been reported in previous studies 5,8 .

\section{Correlations between CSF CRP and CSF Proteins levels}

In the above study it was observed that CRP positivity increases as the protein level in CSF increases. This indicate that probably CRP gain access in CSF through passive across the inflamed meninges rather than its production in CSF. It is suggestive that protein content is partly governed by permeability of blood brain barrier which is altered in CNS infections. However mechanism by which CRP gain access in CSF is not clear. The above finding are in accordance with Philip et $\mathrm{al}^{11}$, Benjamin et al ${ }^{12}$

No direct correlation between positivity of CRP in CSF and total cell count in CSF was observed however positivity increase with cell count.

Table 10: Predictive value of CSF CRP in CNS Infections

\begin{tabular}{|c|c|c|c|c|c|c|c|}
\hline Group & Number & $\begin{array}{c}\text { CRP } \\
\text { Positive }\end{array}$ & $\begin{array}{c}\text { CRP } \\
\text { Negative }\end{array}$ & Sensitivity & Specificity & $\begin{array}{c}\text { Positive } \\
\text { Predictive } \\
\text { value }\end{array}$ & $\begin{array}{c}\text { Negative } \\
\text { Predictive } \\
\text { value }\end{array}$ \\
\hline Pyogenic & 18 & 15 & 3 & $83.3 \%$ & $87.5 \%$ & $75 \%$ & $92 \%$ \\
\hline Tubercular & 20 & 5 & 15 & $25 \%$ & $60.5 \%$ & $25 \%$ & $60.5 \%$ \\
\hline $\begin{array}{c}\text { Viral } \\
\text { Encephalitis }\end{array}$ & 10 & - & 10 & - & - & - & \\
\hline Control & 10 & - & 10 & - & - & - & - \\
\hline
\end{tabular}


Research Article

\section{Conclusion}

Our observations suggest that routine use of CSF CRP may be useful in differentiating bacterial from non bacterial meningitis.

Patient with positive CRP in CSF should be treated as bacterial meningitis. Its value further increases as its results are not altered by prior antibiotic therapy which alters the other routinely used parameters like biochemical value, Cell count and staining results.

Also CSF- CRP can be performed bedside, easy to process and take minimum time and cheap, it can be very useful tool in rapid diagnosis of bacterial meningitis in developing countries.

It can be used in deciding the line of management of overlapping clinical conditions before the results of other routinely used parameters are available.

However, the value of this test for routine clinical use require further evaluation utilizing accurate and precise quantitative assay for measuring CRP level in CSF.

\section{Limitations of study}

We have used a qualitative method which may be responsible for the negative results in patients of pyogenic meningitis as the test might not be able to detect the CRP as it may be below the detection threshold of test.

\section{Acknowledgement}

The authors are thankful to Dr A.C. Nagpal MD, Professor, Department of Medicine and Dr R. K. Jain, Associate Professor and Head, Department of Microbiology, Netaji Subhash Chandra Bose Medical College, Jabalpur, Madhya Pradesh for their constant guidance, supervision and encouragement in conducting this study.

We also thank our patients and their families for participating in the study.

Funding: Nil

Conflict of interest: Nil

Permission from IRB: Yes

International Journal of Medical Research and Review

\section{References}

1. De Beer FC, Kirsten GF, Gie RP, Beyers N, Strachan AF. Value of $\mathrm{C}$ reactive protein measurement in tuberculous,

bacterial, and viral meningitis.Arch Dis Child. 1984;59(7):653-6.

3. Sormunen P, Kallio MJ, Kilpi T, Peltola H. C-reactive protein is useful in distinguishing Gram stain-negative bacterial meningitis from viral meningitis in children. J Pediatr. 1999;134(6):725-9.

4. Peltola HO. C-reactive protein for rapid monitoring of infections of the central nervous system. Lancet. 1982 May 1; 1(8279): 980-2.

5. Clarke D, Cost K. Use of serum C-reactive protein in differentiating septic from aseptic meningitis in children. $\mathrm{J}$ Pediatr. 1983;102(5):718-20.

6. Peltola H, Luhtala K, Valmari P. C-reactive protein as a detector of organic complications during recovery from childhood purulent meningitis. J Pediatr. 1984;104(6):86972 .

7. Tillett WS, Francis T. Serological reactions in pneumonia with a non-protein somatic fraction of pneumococcus. J Exp Med. 1930 Sep 30;52(4):561-71.

8. Corrall CJ, Pepple JM, Moxon ER, Hughes WT. Creactive protein in spinal fluid of children with meningitis. $\mathrm{J}$ Pediatr. 1981;99(3):365-9.

9.Tanner AR, Collins AL, Bull FG. The clinical value of rapid C-reactive protein measurement in cerebro-spinal fluid. Clin Chim Acta. 1985;147(3):267-72.

10. Gray BM, Simmons DR, Mason H, Barnum S, Volanakis JE. Quantitative levels of C-reactive protein in cerebrospinal fluid in patients with bacterial meningitis and other conditions. J Pediatr. 1986;108:665-70. 
11. Philip AG, Baker CJ. Cerebrospinal fluid C-reactive protein in neonatal meningitis.. J Pediatr. 1983(5);102(5):715-7.

12. Benjamin DR, Opheim KE, Brewer L.Is C-reactive protein useful in the management of children with suspected bacterial meningitis? Am J Clin Pathol. 1984 Jun;81(6):779-82.

\section{How to cite this article?}

Patel N, Patel U, Nagpal AC, Jain RK. Evaluating Utility of C- Reactive Protein in Differentiating Bacterial from NonBacterial Meningitis in Tertiary care Hospital, in Central India. Int $\mathrm{J}$ Med Res Rev 2013;1(2):47-55. doi: 10.17511/ijmrr.2013.i02.02 